in vitroに拈ける泌尿器系悪性腫瘍に対する 上皮成長因子（EGF）の影響

日本医科大学泌尿器科学教室 (主任：秋元成太教授）
服部 智任 寺島 保典 原 或 成太

\title{
IN VITRO EFFECTS OF EPIDERMAL GROWTH FACTOR (EGF) ON GROWTH OF UROLOGICAL MALIGNANT TUMOR CELLS
}

\author{
Tomotaka Hattori, Yasunori Terashima, Makoto Hara and Masao Akimoto \\ Department of Urology, Nippon Medical School
}

(Director: Prof. M. Akimoto)

It is well known that Epidermal Growth Factor (EGF) is a cell-regulating factor for variety of tissues in vitro including normal and malignant cells. Furthermore, Takano et al reported that a decreased expression of EGF receptor in clones of human cancer KB cell line might be one of the pleiotropic properties of multidrug-resistant cells. However, both the influence of EGF on human urological cancer cell lines and the relation between EGF receptors and sensitivities of antitumor drugs on these cell lines have not been fully descrived. We have studied the effects of EGF on growth of 4 transitional carcinoma cell lines of bladder $(\mathrm{TCCaB}), 1$ squamous cell carcinoma cell line of bladder $(\mathrm{SCCaB}), 5$ renal cell carcinoma cell lines $(\mathrm{RCC})$ and 3 prostatic carcinoma cell lines $(\mathrm{CaP})$, as well as the relationship between the number of EGF receptors and drug sensitivities of these cell lines in vitro against methotrexate, vinblastine, adriamycine, cisplatin and etoposide (VP16). The present results determined by the in vitro colony forming efficiency method showed that exogenous addition of EGF to cell cultures at $0.1 \mathrm{ng} / \mathrm{ml}$ stimulated the growth of $\mathrm{SCCaB}$ by $169.0 \%$, and at $1 \mathrm{ng} / \mathrm{ml}$ inhibited that of RCC by $2.9 \% \sim 79.1 \%$, relative to control. The more EGF receptors by ${ }^{125 I-E G F ~ b i n d i n g ~ a s s a y, ~ t h e ~ h i g h e r ~}$ inhibition of VP16 on the growth of these cell lines.

These results suggested that EGF stimulated the gwoth of SCCaB and inhibited the growth of $\mathrm{RCC}$ in vitro, and we found that these phenomena were correlated with neither the number of EGF receptors nor affinities of that receptors. Furthermore, the number of EGF receptors may be correlated with the resistance of VP16 to growth-inhibitory effects.

Key words: urological cancer, epidermal growth factor, drug sensitivity

要旨：現在までに樹立されている 4 つの膀胱移行上皮癌株， 1 つの膀胱扁平上皮癌株， 5 つの腎細胞癌 株と 3 つの前立腺癌株を対象として, in vitroでの上皮成長因子 (EGF) の影響及び EGFレセプター数 とメトトレキセート，ヴィンブラスチン，アドリアマイシン，シスプラチンとェトポシド（VP16）を用 いた制癌剤感受性試験の結果との間の関連について検討を行なった。

それぞれの細胞株に対する影響は, 細胞増殖の指標であるコロニー形成能の結果, EGF 濃度が $0.1 \mathrm{ng} /$ $\mathrm{ml}$ では膀胱扁平上皮癌に拈いて, コントロールに対し $169.0 \%$ の増殖を見た. 又, 腎細胞癌では EGF 濃 度 $1 \mathrm{ng} / \mathrm{ml}$ で2.9\% 79.1\%のコロニー形成能であった. 一方, ${ }^{125} \mathrm{I}-\mathrm{EGF}$ 用いたレセプターアッセイの 結果, EGFレセプター数の多い癌細胞株はVP16に対して, より感受性が高かった。

今回の結果は in vitroに㧍ける EGF が, 膀胼扁平上皮癌に対しその増殖を促進し, その一方で腎細胞 癌ではその増殖を抑制する事が示唆された。 また EGF の作用とレセプター数及びレセプターと EGF 間 の親和性との間に関連はみられなかったものの制癌剤に対する感受性との間では, EGF レセプター数が VP16に対する抵抗性と関連している可能性が推測された。 キーワード：泌尿器系悪性腫瘍，上皮成長因子，制癌剂感受性 


\section{緒言}

Cohen らによって発見された上皮成長因子(Epidermal Growth Factor, EGF ${ }^{122)}$ は，正常上皮のみなら ず種々の癌細胞の増殖に多彩な影響を及ぼす事が報告 されている，又，癌遺伝子のひとつである erb-Bによ り産生される蛋白と上皮成長因子レセプター（EGFレ セプター）との相似性なども証明されており，様々な 点で注目されている ${ }^{3) ~ 6) . ~}$

近年, EGF に限らず様々な成長因子についての癌細 胞に対する作用が検討されているが，Sporn らはそれ らの作用は一定ではなく, 標的となる癌細胞の種類や, 細胞周囲環境の違いによる異なるとする，いわゆる multifunctional effect を提唱している1112).

又, 乳癌では EGFレセプターの発現は原発巣より

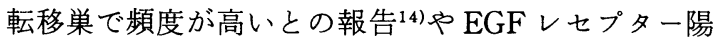
性乳癌では腋窝リンパ節転移の頻度が高い傾向にある とする報告もみられる15)。攵の他に制癌剂に対する多 剂性因子である mdr 1遺伝子の発現をみることにより EGFレセプター数が減少するといった薬剤耐性との 関連についての実験もみられる ${ }^{16)}$.

しかしながら泌尿器系悪性腫瘍に対する EGF の作

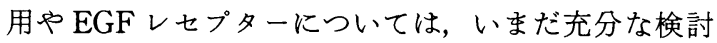
がなされているとは言劣ない.今回我々は in vitroに おける EGF の泌尿器系悪性腫瘍に対する影響及び EGF レセプターとの関連, 加えて先に述べた制癌剂に 対する耐性の点に注目し, 制癌剂の感受性と EGFレ セプターとの関連について検討した。

\section{実験材料及び実験方法}

\section{1. 培養細胞及び培養方法}

使用した培養細胞株は, SCaBER（膀胱扁平上皮 癌), T24, 5637, EJ-1, TCCSUP(以上, 膀胼移行上 皮癌), ACHN, A498, A704, Caki2, NRC12(以上, 腎細胞癌) と PC3, DU145, TSU-Prl (以上, 前立腺 癌)である。また SCaBER, 5637, TCCSUP, ACHN, A498, A704, Caki2, PC3, DU145は ATCC(American Type Culture Collection，大日本製薬）上り， $\mathrm{NRC12}$ は免疫生物研究所より購入した。 T24と EJ-1は Japan Cancer Research Resources Bankょり, TSU-Pr1は 帝京大学泌尿器科飯泉講師より提供された。

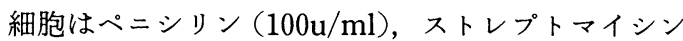
$(100 \mu \mathrm{g} / \mathrm{ml}), 1 \mathrm{mM} \mathrm{L}$-グルタミン及び50nM 2-メルカ プトェタノールを含む RPMI1640（日水製薬，東京） に10\%牛胎児血清 (Fetal calf serum, FCS, Filtron, Australia, Lot No. 8179)を加えたものを培地として
用い, $37^{\circ} \mathrm{C}, 5 \% \mathrm{CO}_{2}$ の条件下にて培養したものを実験 に供した。

2.コロニー形成能 (Colony Forming Efficiency)

$60 \mathrm{~mm}$ 径の dish に600 1,200個の癌細胞を $10 \%$ FCS 加培地に浮遊させ植光込久, 24時間後, 各濃度の $\mathrm{EGF}$ を加えた $1 \% \mathrm{FCS}$ 加培地と培地交換を行ない, $37^{\circ} \mathrm{C}, 5 \% \mathrm{CO}_{2}$ の条件下で $7 \sim 14$ 日間培養し, その後培 地を捨て $10 \%$ ホルマリンで10分間固定の後， $0.25 \%$ ク リスタルヴァイオレットにて dish上のコロニーを染 色した。 30個以上の細胞よりなるコロニーを実体顕微 鏡下にカウントし，コントロールに対するパーセン テージをコロニー形成能とした. 又, 実験は全て triplicate で $2 \sim 3$ 回行なった.

3. 世代時間 (Generation time)

$35 \mathrm{~mm}$ 径の dish に $10^{4}$ 個/dish の癌細胞を用い, コロ 二ー形成能を求めた時と同様の方法で EGFを加え, 3 日目と 7 日目にそれぞれの細胞数をコールターカウ ンター (Coulter electronics, Inc.; U.S.A.) にてカウ ントした，得られたデータを以下に挙げる公式に当て はめ，世代時間を求めた ${ }^{17)}$.

Generation time $=\frac{\log 2(96 \mathrm{hr})}{\log \left(\mathrm{N}_{7} / \mathrm{N}_{3}\right)}$

$\mathrm{N}_{3}$ and $\mathrm{N}_{7}$ : The number of tumor cells on day 3 and day 7

4. ${ }^{125} \mathrm{I}-\mathrm{EGF}$ を用いた EGFレセプターアッセイ

Rolando Prez らの方法 ${ }^{18)}$ に若干の修正を加えた方 法で行なった。即ち24穴プレートの各ウェルに癌細胞 を植光込み confluent になった所で $1 \%$ 牛胎児血清ア ルブミン (bovine serum albumine, BSA, Sigma, U.S.A.) 加の培地に一定量の ${ }^{125}$ I-EGF (NEN, U.S.A.) と非標識 $\mathrm{EGF}$ を加え, EGF の最終濃度が0〜100ng/ $\mathrm{ml}$ となるように培地交換を行ない $4{ }^{\circ} \mathrm{C}$ にて 2 時間放 置. その後末反応の ${ }^{125}$ I-EGF を $1 \% \mathrm{BSA}$ 加培地にて 3 回洗浄する事で取り除き, 次に $1 \mathrm{~N}$ の $\mathrm{NaOH}$ で各ウ エルの細胞を融解させた。 $\gamma$-カウンターにて EGFレ セプターと結合している ${ }^{125}$ I-EGF のカウント行ない Scatchard プロットよりレセプター数並びに解離定数 （Kd）を求めた.

\section{5. 制癌剂感受性試験}

今回用いた制癌剂は, メトトレキセート (MTX), ヴィンブラスチン(VBL), アドリアマイシン(ADM), シスプラスチン (CDDP)，エトポシド(VP16)の 5 剂 であり,それぞれ濃度は MTX $0.45 \mu \mathrm{g} / \mathrm{ml}, \mathrm{VBL} 0.01$ $\mu \mathrm{g} / \mathrm{ml}$, ADM $0.04 \mu \mathrm{g} / \mathrm{ml}$, CDDP $0.2 \mu \mathrm{g} / \mathrm{ml}$, VP16 
では $0.1 \mu \mathrm{g} / \mathrm{ml}$ にて行なった。感受性試験の方法は, ほ ぼFrancis Mcgovern らの方法19)を用いた。具体的に は, $60 \mathrm{~mm}$ 径の dish に癌細胞を $300 ５ 00$ 個， $10 \% \mathrm{FCS}$ 加培地に浮遊させ植え込久24時間後に各種制癌剂を添 加した $10 \% \mathrm{FCS}$ 加培地と培地交換を行なった。またコ ントロールとしては制癌剂無添加の $10 \% \mathrm{FCS}$ 加培地 を用いた。制癌剂と 1 時間接触させた後， dish より培 地を取り除さ Hanks' Balanced Salt Solution （HBSS）にて dish 3 回洗浄した。再び10\%FCS 加 培地を dish に加え，更に 6 日間培養し，その後培地を 捨て $10 \%$ ホルマリンで10分間固定の後， $0.25 \%$ クリス タルヴァイオレットにてdish 上のコロニーを染色し た。30個以上の細胞よりなるコロニーを実体顕微鏡下 にカウントし、コントロールに対する抑制率を求めた。

図 1 コロニー形成能よりみた膀胱癌に対する EGF の効果

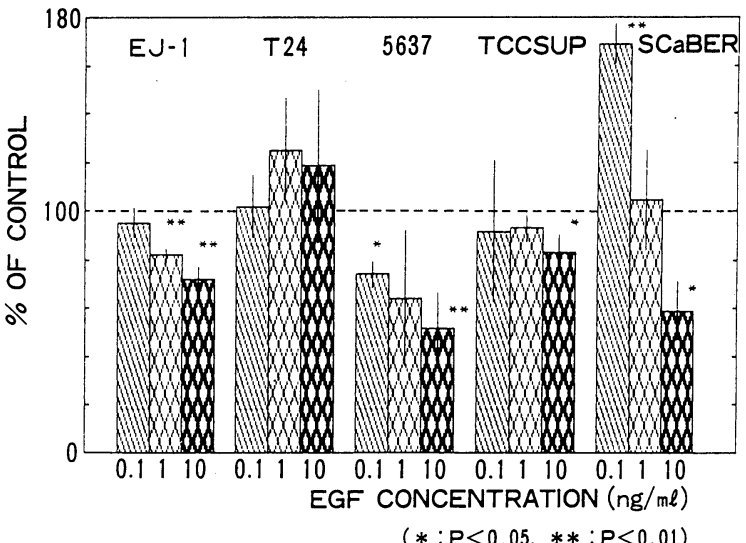

図 2 コロニー形成能よりみた腎細胞癌に対する $\mathrm{EGF}$ の効果

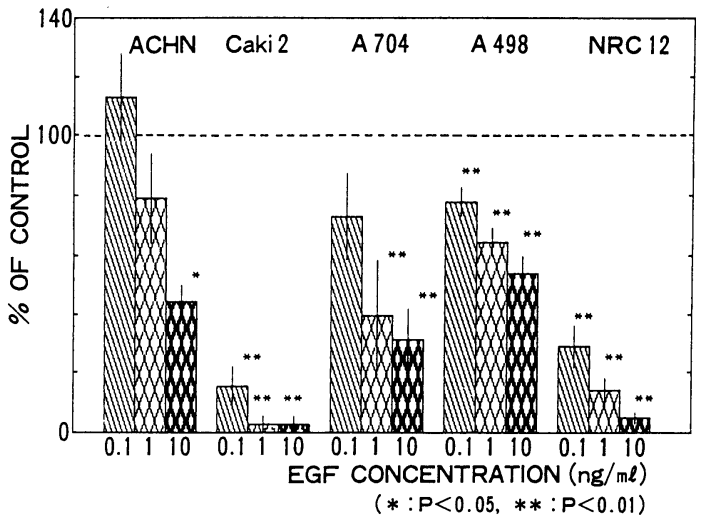

成 績

1.コロ $ン$ 形成能

膀胱癌の内，移行上皮癌では EGF を加える事によ り増殖の軽度促進効果からやや抑制される様子がうか がえたが，特に一定の傾向はみられなかった。それに 対し扁平上皮癌では，明らかに $\mathrm{EGF}$ 添加により増殖 促進効果がみられた（図 1 )。

腎細胞癌では 5 株の全てに濃度依存性に増殖抑制効 果がみられ，その作用機構に興味が持たれた。但し抑 制の程度は培養細胞株によって異なっており, $\mathrm{ng} / \mathrm{ml}$ の $\mathrm{EGF}$ 添加によりコロニー形成能は，2.9\% 79.1\% と開きがあった（図 2 ).

最後に前立腺癌についてであるが, PC3では EGF の 効果はほとんどみられないが他の 2 株では抑制効果が みられた（図 3 ）。

\section{2. 世代時間}

世代時間もコロニ一形成能同様に，癌細胞のいわゆ る増殖の程度を反映しているものと考えられている。

まず膀胱癌であるが，コロニー形成能でみらられた と同じく，膀胼扁平上皮癌で増殖促進効果がみられた (表 1 ).

腎細胞癌では 5 株の内 2 株に増殖抑制効果がみられ たが，残りの 3 株に対する影響はみられなかった（表 2).

前立腺癌の増殖に対し $\mathrm{EGF}$ は特に影響を及ぼして いなかった（表 3 ）.

以上の結果を表 1 〜表 3 に示したが，ここで注目す べき事は先に示したコロニー形成能の結果との解離が 一部の癌細胞株にみられたことである。この理由とし

図 3 コロニー形成能よりみた前立腺癌に対する $\mathrm{EGF}$ の効果

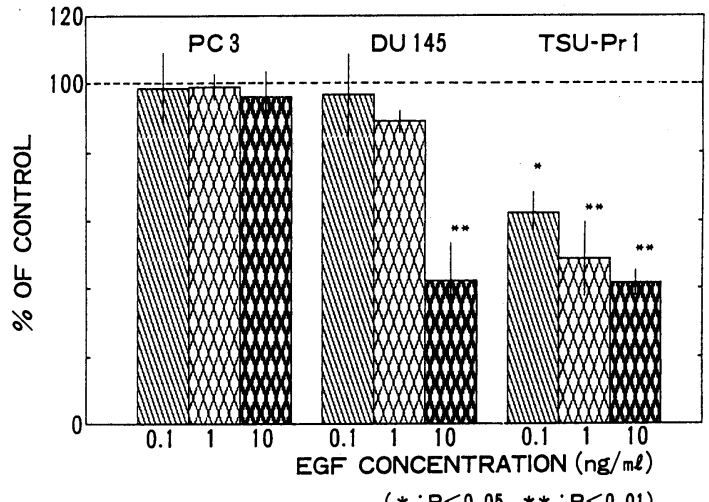

$(*: P<0.05, * *: P<0.01)$ 
Generation Time (hrs)

表 1 各 $\mathrm{EGF}$ 濃度における膀胀癌の世代時間

\begin{tabular}{l|c|c|c|c}
\hline \multirow{2}{*}{} & \multirow{2}{*}{ Control } & \multicolumn{3}{|c}{ EGF concentration $(\mathrm{ng} / \mathrm{ml})$} \\
\cline { 3 - 5 } & & 0.1 & 1 & 10 \\
\hline EJ-1 & $29.65 \pm 0.89^{\#}$ & $27.80 \pm 0.54$ & $27.95 \pm 0.16$ & $32.30 \pm 0.31$ \\
T24 & $40.56 \pm 1.78$ & $38.46 \pm 1.14$ & $41.12 \pm 0.05$ & $45.25 \pm 0.64$ \\
5637 & $30.04 \pm 0.80$ & $32.60 \pm 1.00$ & $32.96 \pm 0.05$ & $34.03 \pm 0.55$ \\
TCCSUP & $35.46 \pm 0.65$ & $34.15 \pm 0.73$ & $31.56 \pm 0.35^{* *}$ & $29.92 \pm 0.48^{* *}$ \\
SCaBER & $59.56 \pm 3.77$ & $34.40 \pm 2.21^{* *}$ & $33.59 \pm 0.16^{* *}$ & $33.19 \pm 0.42^{* *}$ \\
\hline \multicolumn{4}{|c}{} & \multicolumn{3}{c}{ \# mean \pm S.D. ${ }^{* *}: \mathrm{p}<0.01$}
\end{tabular}

表 2 各 EGF 濃度に拈ける腎細胞癌の世代時間

Generation Time (hrs)

\begin{tabular}{|c|c|c|c|c|}
\hline & \multirow{2}{*}{ Control } & \multicolumn{3}{|c|}{ EGF concentration $(\mathrm{ng} / \mathrm{ml})$} \\
\hline & & 0.1 & 1 & 10 \\
\hline $\mathrm{ACHN}$ & $29.99 \pm 0.46^{\#}$ & $31.34 \pm 0.55$ & $32.96 \pm 0.63$ & $31.86 \pm 0.64$ \\
\hline Caki2 & $40.02 \pm 0.60$ & $113.06 \pm 6.94^{* *}$ & $139.37 \pm 4.14^{* *}$ & $197.40 \pm 46.75$ \\
\hline A704 & $77.33 \pm 5.51$ & $72.45 \pm 1.40$ & $63.88 \pm 4.72$ & $77.24 \pm 11.57$ \\
\hline A498 & $37.53 \pm 1.00$ & $39.57 \pm 0.72$ & $41.26 \pm 0.08$ & $43.97 \pm 1.78$ \\
\hline NRC12 & $90.70 \pm 6.50$ & $144.99 \pm 5.39^{*}$ & $207.54 \pm 26.39$ & $214.13 \pm 5.99^{* *}$ \\
\hline
\end{tabular}

表 3 各 $\mathrm{EGF}$ 濃度に抢ける前立腺癌の世代時間

Generation Time (hrs)

\begin{tabular}{l|c|c|c|c}
\hline \multirow{2}{*}{ Control } & \multicolumn{3}{|c}{ EGF concentration (ng/ml) } \\
\cline { 3 - 5 } & & 0.1 & 1 & 10 \\
\hline PC3 & $35.53 \pm 1.78^{\#}$ & $37.52 \pm 0.50$ & $37.47 \pm 0.31$ & $37.43 \pm 1.25$ \\
DU145 & $51.14 \pm 0.91$ & $50.42 \pm 1.30$ & $48.88 \pm 2.34$ & $44.20 \pm 0.49^{*}$ \\
TSU-Pr1 & $31.20 \pm 0.77$ & $30.03 \pm 0.53$ & $30.14 \pm 0.12$ & $30.99 \pm 0.14$ \\
\hline
\end{tabular}

て、コロニー形成能で反応を示した癌細胞株の中に,

EGF に反応しない, 或いは逆の反応を示すようなサブ クローンが存在し，世代時間においてはそのサブク ローンの EGF に対する反応が，結果として反映した ことに依りそれぞれの結果に解離が見られたものと考 えられる。

3.レセプター数並びに解離定数と各癌細胞株の EGF に対する反応性との関連

レセプター数並びに解離定数を表 4 〜表 6 に示し た. 膀胱癌では移行上皮癌である $\mathrm{EJ}-1$ と扁平上皮癌の SCaBER でレセプター数がほぼ同じであるのにも関 わらず，EGFによる反応には大きな差がみられた。腎 細胞癌では総じて膀胱癌や前立腺癌よりもレセプタ一 数が多いようである．解離定数をみると前立腺癌で低 い傾向がみられた。
又,コロニー形成能とレセプタ一数，世代時間とレ セプター数の相関を検討したがいずれも相関はみられ ず，解離定数についても同様であった，従って，各癌 細胞株の EGF に対する反応はレセプタ一数や親和性

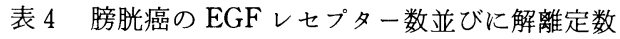
EGF receptors

\begin{tabular}{l|c|c}
\hline & Kd (nM) & Receptors/cell \\
\hline EJ-1 & 0.4 & $\begin{array}{c}37000 \\
\text { (high affinity) } \\
110000 \\
\text { (low affinity) } \\
\text { T24 }\end{array}$ \\
5637 & 2.3 & 8100 \\
TCCSUP & 0.2 & 6100 \\
SCaBER & 0.5 & 2400 \\
\hline
\end{tabular}




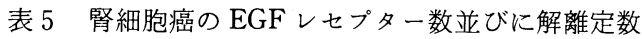
EGF receptors

\begin{tabular}{|c|c|c|}
\hline & $\mathrm{Kd}(\mathrm{nM})$ & Receptors/cell \\
\hline \multirow[t]{2}{*}{ ACHN } & 0.2 & $\begin{array}{c}14000 \\
\text { (high affinity) }\end{array}$ \\
\hline & 1.6 & $\begin{array}{c}42000 \\
\text { (low affinity) }\end{array}$ \\
\hline \multirow[t]{2}{*}{ Caki2 } & 0.2 & $\begin{array}{c}8700 \\
\text { (high affinity) }\end{array}$ \\
\hline & 2.4 & $\begin{array}{c}24000 \\
\text { (low affinity) }\end{array}$ \\
\hline \multirow[t]{2}{*}{ A704 } & 1.1 & $\begin{array}{c}45000 \\
\text { (high affinity) }\end{array}$ \\
\hline & 4.0 & $\begin{array}{c}84000 \\
\text { (low affiinity) }\end{array}$ \\
\hline A498 & 0.5 & 13000 \\
\hline NRC12 & 0.5 & 27000 \\
\hline
\end{tabular}

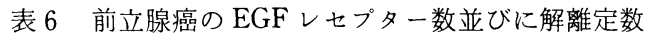
EGF receptors

\begin{tabular}{|c|c|c|}
\hline & $\mathrm{Kd}(\mathrm{nM})$ & Receptors/cell \\
\hline PC3 & 0.3 & 9100 \\
\hline \multirow[t]{2}{*}{ DU145 } & 0.2 & $\begin{array}{c}1500 \\
\text { (high affinity) }\end{array}$ \\
\hline & 0.8 & $\begin{array}{c}2700 \\
\text { (low affinity) }\end{array}$ \\
\hline TSU-Pr1 & 0.2 & 20000 \\
\hline
\end{tabular}

によって規定されるのではなく, EGF とそのレセプ ターが結合することにより生じた細胞内でのシグナル の違いによるものではないかと推測される。

4. 制癌剂感受性と EGFレセプターとの関連

MTX, VBL, ADM, CDDP に対する感受性と EGF レセプター数との関連をみると,それらの間には何ら 相関はみられなかった。一方, 図 4 に示す通りVP16に 対する感受性と EGFレセプター数との間には正の相 関がみられた。つまり EGFレセプターの数が増える に従い, VP16に対する各癌細胞の感受性が増大した.

\section{考 察}

癌細胞の増殖機構の一つとして, 種々の Growth factorによる Autocrine 或いはParacrine theory が 提唱されてから ${ }^{20)}$ ，いわゆる癌の増殖に扔ける Growth factorの重要性が注目されてきた. なかでも EGFについては現在まで様々な種類の癌細胞に対す る効果の検討がなされている.

その他にも, EGFレセプターの発現と予後や, 転移 能との関係, 或いは抗癌剂に対する多剂耐性遺伝子で
図 4 VP16に対する感受性と EGFレセプタ一数と の関係

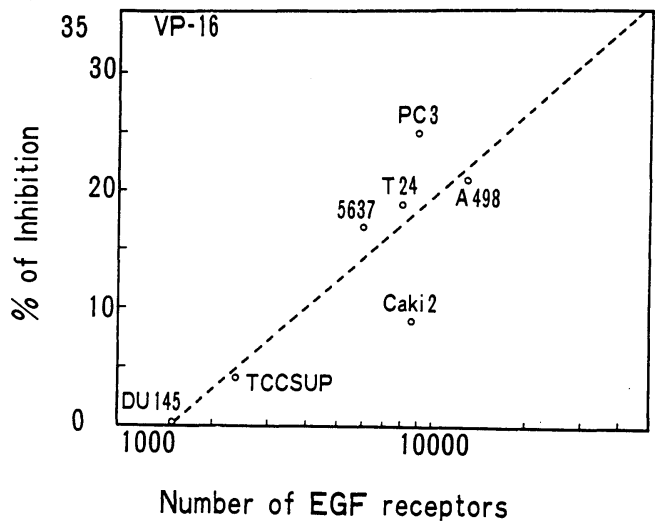

ある $\mathrm{mdr}$ 1と EGFレセプターの発現程度との関連な どが議論されている。

そこで今回我々の行なった実験であるが，主に次に 挙げるような点に留意して行なった。つまり，1）EGF が泌尿器系悪性腫煌に及ぼす作用，並びにそれらの作 用と EGF レセプターとの関連, 2) EGFレセプター数 が制癌剂の多剂耐性遺伝子たる $\mathrm{mdr} 1$ と関連している 可能性があることより, 制癌剤に対する各癌細胞の感 受性と EGFレセプター数との関連の以上 2 点につい て検討を行なった。

1)の内，まず膀朕癌についてであるが，本実験の成 績からは膀胱移行上皮癌に対する EGFによる効果が わずかであるのに対し，膀胱扁平上皮癌では增殖促進 効果がみられた。 in vitro の結果からだけではあるが, 尿中に活性型の EGF が含まれている事実と考兄合わ せると, 膀胱扁平上皮癌の進行に $\mathrm{EGF}$ が関与してい る可能性も考えられよう.

しかしながら膀胱移行上皮癌においても EGFレセ プターのみに着目すると, 正常膀胱粘膜に拈いては,

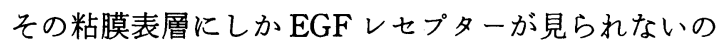
に対して，それら粘膜が癌化した場合，EGFレセプ ターの無秩序な発現が見られる事は, 病理組織標本の 免度化学組織染色にて既に確認されている21). 即ち, 膀 胼移行上皮癌にとって EGF レセプターは癌化に伴う 二次的な变化として発現してきたものとも考学られよ 5.

次に EGF の腎細胞癌に対する効果であるが，個々 の細胞の増殖に対して, 抑制的な作用がみられた. 又, Leonard G. Gomella らは in vitro で TGF- $\beta$ (Trans- 
forming Growth Factor- $\beta$ ) により腎細胞癌の増殖が

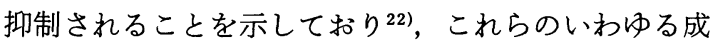
長因子の腎細胞癌に対する増殖抑制の機構を明らかに する事は，進行性腎細胞癌に対する治療法を考兄る上 で有用であろら。

前立腺癌の増殖に対して $\mathrm{EGF}$ の影響は一定ではな いししかしながら EGFレセプターに注目すると, 前立 腺癌同様のホルモン依存性の癌である乳癌では, その 悪性度が高くなるにつれェストロジェンレセプターが 消失し EGFレセプターの発現をみるとの報告もみら れる ${ }^{15)}$. Jackson E. Fowler, Jr. らは前立腺癌の病理 組織標本を用い, EGFレセプターに対するモノクロー ナル抗体で免疫化学組織染色を行なっているが，そこ では Gleason score が高いほどEGFレセプターの発 現をみ，ホルモン療法を施行する事により EGFレセ プターの発現頻度が高くなると報告している ${ }^{23)}$.つま り前立腺癌に㧊いても悪性度が高いものや，ホルモン 療法の施行によりアンドロジェンレセプターが消失 し, EGFレセプターが発現してきているのではないか と想像できる。

以上膀胱癌, 腎細胞癌と前立腺癌に対する EGF の 影響について述べたが，それらの影響と EGFレセプ ターの数や親和性との相関は何等みられなかった。こ れは EGF が単純な伝達物質としての因子ではなく,

標的となる細胞の周囲環境や, 細胞内の種々の因子に よりその作用が決定される複雑な働きをするためであ ろらと想像される。

またその一方で EGFレセプターは, 先にも述べた 通り細胞の癌化に伴ら二次的な変化である可能性も充 分に考えられる。

2)については今回全ての癌細胞株に対して制癌剂感 受性試験を行ならことが出来なかったが, 得られた結 果からはEGFレセプター数とVP16に対する感受性 のみに相関がみられた. 即ち EGFレセプター数の少 ない癌細胞株の方がVP16に対して抵抗性であるとの 結果であった。

さてVP16に対する薬剤耐性の機構についてである が現在のところ薬剤の能動的細胞外排出や, VP16の標 的である DNA トポイソメラーゼとの関連もあるので はないかと考兄られている24). 今回の結果からは, P-糖 蛋白の様に VP16を細胞外に排出する機構や DNA ト ポイソメラーゼを規定している因子と，EGFレセプ ター数を規定している因子とが何らかの関連を持って いる可能性が示唆される。 また, Takano らが述べてい
るような $\mathrm{ADM}$ とGFレセプター数との直接の関連 はみられなかったが，これは用いた癌細胞株に於いて mdr 1遺伝子により産生される P-糖蛋白が励起されて いる状態であったとは必ずしも言えないことによるた めかもしれない，今後, 更に様々な角度から検討を加 える必要があろう。

\section{結 語}

1. 膀胼癌細胞株, 腎細胞癌株之前立腺癌株を用い, それらの増殖に対する EGF の効果を、コロニー形成 能及び世代時間にて検討した。

2. 更にそれらの EGFレセプターについて ${ }^{125}$ I-EGF を用いレセプターアッセイを行なった。

3. $\mathrm{EGF}$ は膀胱扁平上皮癌細胞の増殖を促進したが 移行上皮癌では特定の作用がみられなかった。

4. 腎細胞癌株の増殖に対しては抑制効果を示した。

5. 前立腺癌に対して EGF は影響をほとんど及ほ さないかその増殖を抑制した。

6. EGF の及ぼす影響とそのレセプター数及び解離 定数の間に関連はなかった。

7. EGFレセプター数が少ない癌細胞株に於て VP16に対する薬剤抵抗性が認められた。

今回使用した TSU.Pr1を提供してくださった帝京大学 泌尿器科講師 飯泉達夫先生並びに EJ-1，T24の供給を受 けました Japan Cancer Research Resources Bank に謝意 を表します。 又, 実験助手をつとめられた佐藤純子嬢に感謝 致します。

本論文の要旨の一部は第76回日本泌尿器科学会総会, 第 26 回日本癌治療学会, 第 48 回日本癌学会及び第 85 回アメリ 力泌尿器科学会にて報告した。

本研究の一部は平成元年度文部省科学研究費奖励研究 （A）01771246によりなされたことを付記する。

\section{文献}

1) Cohen, S.: Purification and metabolic effects of a nerve growth-promoting protein from snake venom, J. Biol. Chem., 234, 1129-1137, 1959.

2) Cohen, S.: Isolation of a mouse submaxillary gland protein accelerating incisor eruption and eyelid opening in the new-born animal, J. Biol. Chem., 237, 1555-1562, 1962.

3) Yamamoto, T., Nishida, T., Miyajima, N., Kawai, S., Ooi, T. and Toyoshima, K.: The erbB gene of avian erythroblastosis virus is a member of the src gene family. Cell, 35, 71-78, 1983.

4) Downward, J., Yarden, Y., Mayes, E., Scrace, 
G., Totty, N., Stockwell, P., Ullrich, A., Schlessinger, J. and Waterfild, M.D. : Close similary of epidermal growth factor receptor and v-erbB oncogene protein sequences. Nature, 307, 521-527, 1984.

5) Ullrich, A., Coussens, L., Hatflick, J.S., Dull, T. J., Gray, A., Tam, A.W., Lee, J., Yarden, Y., Libermann, T. A., Schlessinger, J., Downword, J., Mayes, E.L.V., Whitle, N., Waterfield, M.D. and Seeburg, P.H.: Human epidermal growth factor receptor cDNA sequence and aberrant expression of the amplified gene in A431 epidermoid carcinoma cells. Nature, 309, 418-425, 1984.

6) 山本 雅, 柳沢亜古: erbB 関連増殖因子レセプ タ一。蛋白質・核酸·酵素，31，1052-1056， 1986.

7) Cowley, G., Smith, J.A., Gusterson, B., Hendler, F. and Ozanne, B.: The amount of EGF receptor is elevated on squamous cell carcinoma. Cancer Cells, 1, 5-10, 1984.

8) Yamamoto, T., Kamata, N., Kawano, H., Shimizu, N., Kuroki, T., Toyoshima, K., Rikimaru, K., Nomura, N., Ishizaki, R., Pastan, I., Gamou, S. and Shimizu, N.: High incidence of amplification of the epidermal growth factor receptor gene in human squamous carcinoma cell lines. Cancer Res., 46, 414-416, 1986.

9) Ozawa, S., Ueda, M., Ando, N., Abe, O. and Shimizu, N.: High incidence of EGF receptor hyperproduction in esophageal squamous-cell carcinomas. Int. J. Cancer, 39, 333-337, 1987.

10) Kamata, N., Chida, K., Rikimaru, K., Horikoshi, M., Enomoto, S. and Kuroki, T.: Growthinhibitory effects of epidermal growth factor and over expression of its receptors on human squamous cell carcinomas in culture. Cancer Res., 46, 1648-1653, 1986.

11) Gamou, S., Kim, Y.S. and Shimizu, N.: Different responses to EGF in two human carcinoma cell lines, A431 and UCVA-1, possessing high numbers of EGF receptors. Mol. Cell Endocrinol., 37, 205-213, 1984.

12) Sporn, M.B. and Roberts, A.B.: Peptide growth factors are multifunctional. Nature, 332, 217-219, 1988.

13) Carpenter, G.: Epidermal growth factor. Ann. Rev. Biochem., 48, 193-216, 1979.
14) Sainsbury, J.R.C., Farndon, J.R., Sherbet, G.V., et al.: Epidermal growth factor receptors and oestrogen receptors in human breast cencer. Lancet, 16, 1398-1402, 1985.

15）中村隆志, 浜田雄蔵, 向田秀則, 田中 卓, 谷本雅 博, 新本 稔, 服部孝雄：ヒト乳がんに括ける Epidermal Growth Factor Receptor の発現と臨 床病態 (Competitive Binding Assay を中心とし て). 癌と化学療法, 15, 2737-2741, 1988.

16) Takano, H., Kohno, K., Shiraishi, N., Sato, S., Asoh, K., Yakushinji, M., Ono, M. and Kuwano, M. : Altered expression of epidermal growth factor receptor gene in a classical multidrugresistant variant of a human cancer cell line. KB. Jpn. J. Cancer Res., 80, 373-379, 1989.

17) Messing, E.M. and Reznikoff, C.A.: Normal and malignant human urothelium: In vitro effects of epidermal growth factor. Cancer Res., 47, 2230-2235, 1987.

18) Pérez, R., Pascual, M., Macias, A., Lage, A.: Epidermal growth factor receptors in human breast cancer. Breast Cancer Res. Treat., 4, 189-193, 1984.

19) Mcgovern, F., Kachel, T., Vijan, S., Schiff, S., Lin, C.W. and Prout, G.R. Jr.: Establishment and chractoterization of a doxorubicinresistant human bladder cancer cell line (MGHU1R). J. Urol., 140, 410-414, 1988.

20) Sporn, M.B. and Todaro, G.J.: Autocrine secretion and malignat transformation of cells. N. Engl. J. Med., 303, 878-880, 1980.

21) Lau, J.L., Fowler, J.E. Jr. and Ghosh, L.: Epidermal growth factor in the normal and neoplastic kidney and bladder. J. Urol., 139, 170-175, 1988.

22) Gomella, L.G., Sargent, E.R., Linehan, W.M. and Kasid, A.: Transforming growth factorbeta inhibits the growth of renal cell carcinoma in vitro. J. Urol., 141, 1240-1244, 1989.

23) Fowler, J.E. Jr., Lau, J.L.T., Ghosh, L., Millis, S. E. and Mounzer, A. : Epidermal growth factor and prostatic carcinoma: An immunohistochemical study. J. Urol., 139, 857-861, 1988.

24) Moscow, J.A. and Cowan, K.H.: Multidrug resistance. J.N.C.I., 80, 14-20, 1988.

(1990年 6 月 5 日受理) 